\title{
Recruitment Strategies for a Sustainable Pipeline of African American College Graduates as Civil Servants
}

\author{
Owen W. Muldrow, Jr. \\ Oklahoma Department of Transportation
}

\author{
Keri L. Heitner \\ Walden University
}

Government leaders have not been successful in their strategies for developing a pipeline of African American college students to address the absence of African American representation in civil service management positions. The civil service's pipeline of African American college graduates is insufficient for demand. The purpose of this qualitative modified Delphi study was to build consensus among a nationwide expert panel of government-affiliated talent managers regarding a grand strategy for creating a sustainable civil service pipeline of annual graduating classes of African American collegians. The panelists' generated six solutions, which represented the grand strategy for this civil service pipeline.

Keywords: African American representation, civil service, diversity and inclusion, grand strategy, recruitment, social change

\section{INTRODUCTION}

The talent pipeline is an essential component for fulfilling the mission and long-term sustainability of an organization (Ross, Wells, \& Clarke, 2014; Stewart, 2016). As more students earn college degrees, organizations are interested in graduates to achieve their organizational objectives and to fill roles vacated by turnover (Sabharwal \& Geva-May, 2013). Not only should organizations have talent pipelines, but the pipelines must be diverse (Stewart, 2016). Diverse pipelines contribute to organizations' robust futures by helping develop creative workforces that reflect the communities being served from broad perspectives to adapt to an evolving society (Cauchon, 2017; U.S. Department of Justice and Equal Employment Opportunity Commission [U.S. DOJ \& EEOC], 2016). Kerr (2015) found that organizations that enhance their workforces' racial diversity achieve a $35 \%$ increase in financial returns.

The U.S. civil service is a merit-based system for equal employment opportunities for all demographic groups and does not meet society's demand for a diverse workforce because the talent pipelines are lacking African American college graduates. Fewer than 20\% of government employees are African American (EEOC, 2018; U.S. Office of Personnel Management [U.S. OPM], 2018). African Americans are underrepresented in mid- to senior-level civil service positions, accounting for $18 \%$ in $2014,19 \%$ in 2016 in the federal government, and decreasing from $13.4 \%$ in 2013 to $11.7 \%$ in 2015 in state and local government (EEOC, 2018; U.S. OPM, 2018). Researchers and scholars contend that the underrepresentation of African Americans in the civil service is a nationwide problem that must be 
addressed (Welsh, 2015; Wilson, 2014). Guidance and initiatives for African American representation in civil service positions have been designated a federal government leadership responsibility (Brooks, Dougherty, \& Price, 2015). Despite the pipeline-building efforts of organizations such as the U.S. Department of Justice, the Equal Employment Opportunity Commission, and the U.S. Office of Personnel Management, the percentage of African American college graduates selecting federal employment opportunities has not shown significant improvement (U.S. DOJ \& EEOC, 2016; U.S. OPM, 2018), and the percentage is not expected to increase (Downs, 2016). Estimates vary of the African American collegians who intend to work in public administration, ranging from $2 \%$ (National Association of Colleges and Employers [NACE], 2014) to 17\% (Downs, 2016). In addition, to correct the issue of diversity at the federal level, President Obama had established Presidential Executive Order 13583 to promote developing and implementing a government-wide strategic plan to improve diversity and inclusion (Nelson, 2015). However, government leaders have not produced the desired outcomes in their strategies to provide proactive employment opportunities for African Americans and other historically deprived groups (Brooks et al., 2015; EEOC, 2013).

The civil service's talent pipeline of African American college graduates is not full enough to fill the demand for entry level and replacement positions for civil service employees (Ross et al., 2014). Building a civil service employment pipeline requires that organizations have attractive qualities for candidates. Attracting candidates is the first stage of talent management, followed by actually hiring employees, training them, maximizing their performance through development, and retaining them (Schiemann, 2014). A fundamental component of building an employment pipeline is recruitment, which consists of sourcing and attracting candidates (Ployhart, Schmitt, \& Tippins, 2017). The talent management concept was originated by the management consultancy McKinsey \& Company in the late 1990s (Festing \& Schafer, 2014) and had an initial focus on recruitment, but since the 21 st century, the priority has been for developing high-potential, high-performance employees (Al Ariss, Cascio, \& Paauwe, 2014; Cappelli \& Keller, 2014). That lost focus has led some civil service officials to ponder if the government can attract young professionals (Boynton, 2015).

Numerous workforce diversity solutions have been attempted in various employment sectors, including the civil service, but efforts to build an employment pipeline of African American college graduates have not yielded desired results. Any strategies for expanding the pipeline have to be on a larger scale in order to make any significant impacts on the civil sector's growth (Sabharwal \& Geva-May, 2013). Collaboration in scaling formal pipeline strategies is difficult for government organizations to achieve because each organization has its own culture and practices (Willem \& Lucidarme, 2014). The ability of government leaders to create desirable and feasible strategies for creating a sustainable pipeline of college graduates for entry-level jobs is questionable. This lack of progress is attributable to the perceptions of government leaders regarding cumbersome logistics for creating a pipeline, loss of organizational power in strategy execution, and time-consuming inefficiencies for maintaining a pipeline (Mitchell, O'Leary, \& Gerard, 2015). Mitchell et al. (2015) explained that NGO (nongovernmental organization) leaders are practical about collaboration, whereas local and federal leaders are guided by values in their pursuit of collaboration.

The problem is the lack of success in building forward-looking strategies for creating a sustainable pipeline of candidates for recruitment into entry-level jobs in the civil service targeted at annual graduating classes of African American college students (EEOC, 2013). Rather than developing shared recruitment solutions and costs, the approach to recruitment among government organizations is fragmented (Mitchell et al., 2015). Individual hiring managers compete just in time for a small available pool of African American college graduates (Gallicano, 2013). Government leaders have not come together with desirable, feasible, forward-looking strategies to address the problem of low African American representation in civil service positions (Mitchell et al., 2015). The purpose of this study was to build consensus among a nationwide expert panel of government-affiliated talent managers as to the desirable and feasible elements and tactics of a forward-looking grand strategy. This grand strategy would be to create a sustainable pipeline of candidates for recruitment into entry-level jobs in the civil service, targeted at annual graduating classes of African American college students. The research question focused on the expert panel's level of consensus in such grand strategy. 
This study is an invaluable resource in establishing the civil service's diverse workforce as collegeeducated African Americans have not been enticed by the civil services' prevailing employment attributes, which are known as normative public service motivation values (Benditt, 2015). Recruitment and outreach need to be tailored to African Americans and to be observed as the first step in breaking the glass ceiling in the civil service (Wilson, 2014). The gap in knowledge this study addressed was the lack of consensus in the desirability and feasibility of the many strategies to build the civil service pipeline of African Americans. The pipeline strategies have been unsuccessful (Hofhuis, van der Zee, \& Otten, 2016) because they were not scaled across the sector and therefore were not impactful (Cunningham, Avner, \& Justilien, 2014). Multiple resource-intensive solutions and ineffective collaboration practices between government organizations may be responsible for not achieving desired goals (Cunningham et al., 2014; NACE, 2014). This manuscript regards the methodology to develop solutions in building the pipeline through a collaborative effort so that an agreed-upon strategy could be applied for the broad government spectrum.

\section{CONCEPTUAL FRAMEWORK}

The theory of strategy was the underlying philosophy for this study regarding the problem of government leaders' lack of success in building forward-looking strategies for recruiting African American college graduates throughout a sustainable employment pipeline. Chamberlain's (2010) theory of strategy, in which he deconstructed a strategy to its elements as delineated by the theory's Proposition 4, was applied to this study. Elements (also known as substrategies or conceptual categories) are the essential thrust of the strategy as each element represents a clear concept directly addressing the delivery of the strategy's general direction and wide path (Chamberlain, 2010). Tactics are the specific actions of how an element supports the strategy and provides the details of an element (Chamberlain, 2010). Determining and understanding the strategy from its elemental features is essential for achieving the strategy's purpose.

Schiemann (2014) opined that a framework of items is required to pinpoint how to recruit African Americans. The theory of strategy does not designate what elements should constitute a given strategy. Strategists are required to assess their respective situations to determine which elements of a strategy are best suited for addressing those situations. For a strategy to be successful, the elements need to be articulated and described.

Grand strategy was the foundational concept for determining the elements and associated tactics of this study's civil service recruitment strategy. The grand strategy is required for creating the pipeline in the civil service for African American graduates because a grand strategy entails the most thorough approach in realizing the pipeline (Layton, 2012). Grand strategy involves the broadest perspective of the three types of strategy - grand, major, and minor - in a strategy's role of providing basic direction to achieve a purpose or objective (Layton, 2012). Strategists adjust their level of perspective for creating the type of strategy necessary (Mintzberg, 1987), thus allowing them to determine the strategy's appropriate elements as propositioned in the theory of strategy (Chamberlain, 2010). Grand strategy represents a social contract between dependencies, such as shareholders, customers, employees, and society, for achieving a unified objective (Bartlett \& Ghoshal, 1994; Chaffee, 1985). Goddard and Krebs (2015) posited that grand strategy entails a national interest in a collective entity aligning national ends with national means. Layton (2012) contended that grand strategy should be viewed as a set of interdependent elements that requires a holistic perspective and enables greater understanding of an objective than the perspective of disaggregated elements (Layton, 2012). Layton also expressed that developing and applying these diverse elements require considerable time but make the grand strategy appropriate for crises that have existed indefinitely when prior approaches to the crisis did not have a holistic perspective. Goddard and Krebs (2015) opined that in a grand strategy, its creators recognize all the relevant elements for addressing both the threats and opportunities in pursuit of the national agenda. The thorough recognition of the elements and tactics in creating a civil service employment pipeline for African American college graduates constitutes a grand strategy with transparency and legitimacy for government and society (Goddard \& Krebs, 2015).

The basis of this study is that previous strategies to build the African American civil service pipeline lacked consensus thus not employed government wide. The objective of this study was to build consensus 
on the strategies on which to scale across government. This study was framed through the theory of strategy and the concept of grand strategy. This framework entailed an exhaustive review of the body of literature on this civil service issue to identify all the relevant published solutions for addressing the civil service African American pipeline. Preliminary investigation enabled the assumption of seven concepts for which to categorize the identified actionable solutions. This identifying process involved precoding the literature for conceptual and actionable solutions, while using a solution matrix for recording the solutions and references discovered in the review of the study. Actionable solutions were delineated as the tactics and the concepts of these actionable solutions were delineated as the elements. The literature in this review consisted of scholarly journals, trade publications, professional associations and institutions, and government documents. The search for these elements and tactics continued until data saturation was met. To mitigate against bias, each tactic distilled from the review was supported by multiple resources. The review enabled the recognition of 57 tactics and confirmation of the initial seven elements (resources, partnership, leadership, business intelligence, community development, technology, and generic benchmarking). Each element supported the grand strategy, which was for creating a sustainable pipeline of candidates for recruitment into entry-level jobs in the civil service targeted at annual graduating classes of African American college students. A literature review writeup covering all these solutions permitted further validation and understanding to the authors' sentiments of these solutions. The compilation of the various notions to address the civil service African American recruitment problem, which are the grand strategy, the theory of strategy and the elements and associated tactics represent the study's conceptual framework. Figure 1 contains the model of the framework.

\section{FIGURE 1 \\ CONCEPTUAL FRAMEWORK FOR CIVIL SERVICE PIPELINE OF AFRICAN AMERICAN COLLEGE GRADUATES}

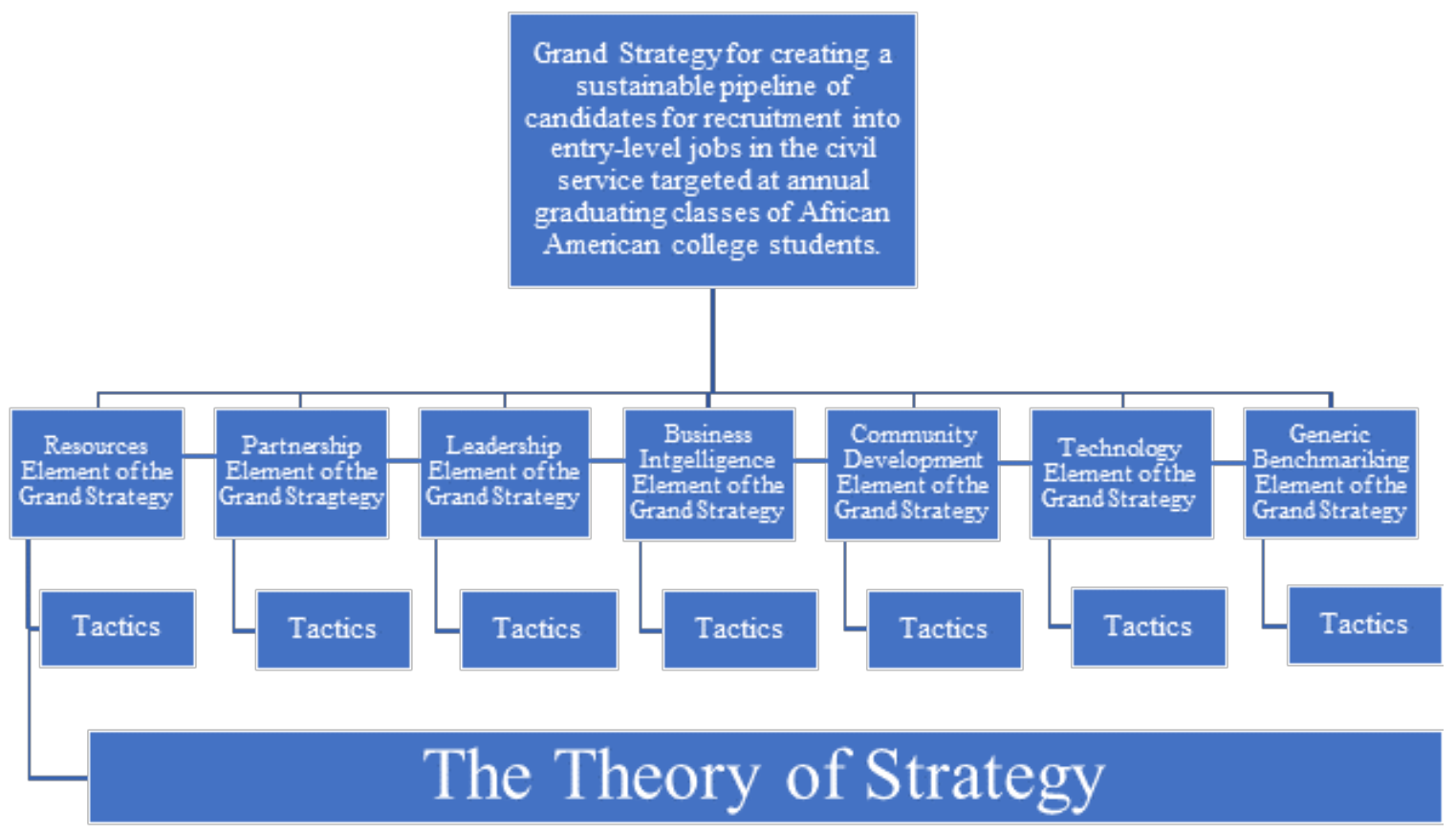

\section{METHOD}

The method for this study was qualitative with a modified Delphi design. Skulmoski, Hartman, and Krahn (2007) opined that the Delphi design is particularly useful when the research goal is to better understand problems, gather solutions, and develop forecasts. The Delphi was appropriate for this study 
because the study objective was to seek solutions and gain consensus of the solutions, which corresponds with the essence of a Delphi (Heitner, Kahn, \& Sherman, 2013). The Delphi design involves the subjective opinions and perceptions of expert participants and the creation of a list of statements to be assessed for agreement or disagreement, derived from the participants' opinions (Brady, 2015). The Delphi is a particular approach for addressing the challenges, multiple dimensions, and practical terms of the public sector (Durant \& Rosenbloom, 2016).

The study's modified Delphi design entailed creating a precoded list of workforce diversity solutions that were established from the conceptual framework, the research inquiry, and the scholarly literature (Miles, Huberman, \& Saldana, 2014). The precoded list is a deviation from the Round 1 of the Classical Delphi's open-ended questionnaire for solutions (Fletcher \& Marchildon, 2014). This deviation constituted the modified Delphi. The provisional start list was based on the published concepts, findings, and interpretations of researchers and practitioners (Patton, 2015). The provisional list was expected to be similar to, if not more exhaustive than, the outcomes from a customary open-ended list because the provisional list would already contain those workforce diversity solutions shared by thought leaders in the literature (Miles et al., 2014). Because of the use of the modified Delphi design and its preconstructed list, the study required less time from the panel members to produce a cogent list of workforce diversity solutions without sacrifice to quality of thought. This study's modified Delphi design included a Likerttype questionnaire, and a ranking questionnaire to facilitate the building of consensus as to the desirability, feasibility, and importance of the solutions for creating a sustainable civil service pipeline of African American college graduates.

\section{Participants}

For this study, individuals qualified to participate in one of the following three ways:

- Any government work experience of at least 10 years in talent acquisition, or

- Any experience of at least 10 years as an internal or contracted human resource or diversity officer with a government organization for at least 10 years, or

- Any experience of at least 10 years as a leader of a talent acquisition company that assists with talent acquisition for a government organization.

Government participants were chosen as they had credible knowledge of the solutions that are desirable and feasible in the civil service. The participants were also experts in their field of talent management, contributing to their greater understanding of what might be desirable and feasible in attracting potential candidates to an organization. The reasons above justified the participants as appropriate for addressing the problem of the study as the research questions involved recruiting African American college graduates into the civil service.

The sample for this study was homogenous. The first participants were identified through the lead author's professional network where snowball sampling commenced thereafter. Snowball sampling involved an average of two participants per referral and a maximum of four participants in any given referral chain. The lead author emailed these interested participants the study announcement that contained the details of the research survey. Individuals who were interested emailed the lead author, and once the minimum requisite panel size of 20 participants was acquired the research survey commenced.

\section{Materials}

The data collection instruments for the study were surveys of four rounds. The list of 57 tactical solutions and categorizing elements based on the review of the body of literature was the source for creating the Round 1 survey, and this survey derived the remaining surveys. Each of these solutions identified in the literature became a solution statement for assessing on the Round 1 survey. Prior to commencing the research survey, the research survey underwent a field test by nonparticipant professionals on the study topic to ensure the statements were coherent and with the necessary content for the participants.

In Round 1, participants had the opportunity to provide any comments about the wording of the solution statements and add solutions to the list. In Round 2 participants rated the desirability and feasibility of each tactic. Desirability refers to the effectiveness of a tactic for addressing a phenomenon, and feasibility refers 
to how practical the tactics will be to implement (Linstone \& Turoff, 2002). Participants rated survey items on 5-point Likert-type scales: (a) $1=$ very undesirable (very unfeasible), (b) 2 = undesirable (unfeasible), (c) 3 = neutral or no opinion, (d) $4=$ desirable (feasible), and (e) $5=$ very desirable (very feasible; Linstone \& Turoff, 2002; Meskell, Murphy, Shaw, \& Casey, 2014). Panelists could also enter brief comments to explain their decisions, particularly for ratings of 1 or 2 .

Round 3 involved a ranking survey where the rankings ranged from 1 for highest ranking to 5 for lowest ranking, with higher ranking numbers indicating greater importance (McMillan, King, \& Tully, 2016). In Round 4, participants rated their confidence in the final list of items on a 5-point Likert-type scale. The confidence scale employed (Linstone \& Turoff, 1975) was a self-reported measure of certainty of how sure the panelist was in the cumulative panel prediction being correct about the items for building the pipeline (Linstone \& Turoff, 2002). The voting dimensions of the confidence scale (Linstone \& Turoff, 1975) were (a) $5=$ certain (low risk of being wrong), (b) $4=$ reliable (some risk of being wrong), (c) $3=$ neither reliable or unreliable, (d) 2 = risky (substantial risk of being wrong), and (e) $1=$ unreliable (great risk of being wrong).

\section{Data Collection, Analysis, and Results}

All the surveys were located on the SurveyMonkey. The study involved four rounds of data collection and analysis over a 13-week period. Each round had a scheduled opening and closing date, but closing dates were extended to maximize participation. Individuals who emailed their notice to participate were provided the link to the Round 1 . The Round 1 contained the informed consent, which required participants to confirm their eligibility in accordance with the criteria for participation to proceed with the research survey. Only the participants who completed the survey of the prior round received the survey link of the subsequent round. Table 1 contains the number of surveys distributed and completed for each round with the response rate.

TABLE 1

SURVEY RESPONSE RATE

\begin{tabular}{lccc}
\hline Round & Surveys distributed & Surveys completed & Response rate $\%$ \\
\hline 1 & 39 & 25 & 64.1 \\
2 & 25 & 19 & 76.0 \\
3 & 19 & 15 & 78.9 \\
4 & 15 & 15 & 100 \\
\hline
\end{tabular}

Round 1

The Round 1 survey site displayed the informed consent followed by the survey of 57 solution statements. The survey was organized by the elements and corresponding tactics. Twenty-five participants completed the Round 1 survey. Of the seven conceptual elements, participants generated 13 revised statements in these three elements: resources, partnership, and business intelligence. Participants also generated the creation of 6 new statements in these elements: resources, partnership, community development, and technology. The Round 1 questionnaire was updated and consisted of 63 statements and presented as the list for Round 2.

\section{Round 2}

The Round 2 survey included the 63 tactical statements (organized by their corresponding elements) converted into Likert-type items for participants' evaluation, and their responses were measured for consensus. Consensus was predefined as a minimum of $70 \%$ frequency for items scoring a 4 or 5 rating on both the desirability and feasibility 5-point Likert-type scales. Items from Round 2 that met consensus were flagged for inclusion in Round 3. Twenty-three items met consensus and became the items for the Round 
3 data collection process for further consensus building. Table 2 contains the 23 tactical statements that met consensus.

\section{TABLE 2 \\ ROUND 2 STATEMENTS SATISFYING CONSENSUS}

\begin{tabular}{|c|c|c|}
\hline \multirow[b]{2}{*}{ Element \& Tactical Statements } & \multicolumn{2}{|c|}{ Feasibility $(\mathrm{F})$} \\
\hline & $\mathrm{D} \%$ & $\mathrm{~F} \%$ \\
\hline $\begin{array}{l}\text { R. Civil service organizations should provide employees and their families quality and } \\
\text { affordable insurance that includes health, dental, vision, disability and life coverages. }\end{array}$ & 100.0 & 89.5 \\
\hline R. Civil service organizations should provide paid leave time. & 100.0 & 89.5 \\
\hline $\begin{array}{l}\text { R. Civil service organizations should provide compensation packages that are competitive } \\
\text { and transparent. }\end{array}$ & 94.7 & 73.7 \\
\hline $\begin{array}{l}\text { R. Civil service organizations should provide career training and development } \\
\text { opportunities. }\end{array}$ & 100.0 & 84.2 \\
\hline $\begin{array}{l}\text { R. Civil service organizations should provide internships to African American college } \\
\text { students. }\end{array}$ & 89.5 & 73.7 \\
\hline R. Civil service organizations should provide writing workshops. & 84.2 & 73.7 \\
\hline $\begin{array}{l}\text { L. Leaders of civil service organizations should embrace both diversity and inclusion to } \\
\text { support the African American pipeline. }\end{array}$ & 94.7 & 84.2 \\
\hline $\begin{array}{l}\text { P. Civil service organizations should recruit from both predominately White institutions } \\
\text { and historically Black colleges and universities. }\end{array}$ & 89.5 & 84.2 \\
\hline P. Civil service organizations should recruit from career institutes for African Americans. & 84.2 & 73.7 \\
\hline $\begin{array}{l}\text { P. Civil service organizations should recruit at professional workshops and conferences } \\
\text { of African Americans. }\end{array}$ & 89.5 & 78.9 \\
\hline P. Civil service organizations should recruit from STEM program organizations. & 84.2 & 78.9 \\
\hline $\begin{array}{l}\text { B. Civil service organizations should require all civil service employees to complete } \\
\text { cultural competency/ cultural intelligence programs. }\end{array}$ & 78.9 & 73.7 \\
\hline $\begin{array}{l}\text { C. Civil service organizations should include the phrases "EEO organization" and } \\
\text { "diversity management" on job announcements. }\end{array}$ & 78.9 & 78.9 \\
\hline $\begin{array}{l}\text { C. Civil service organizations should market/Brand the organizational mission to support } \\
\text { social goals and how the organization's efforts have helped the social value of the } \\
\text { community. }\end{array}$ & 73.7 & 73.7 \\
\hline $\begin{array}{l}\text { C. Civil service organizations should participate in community activities and stay } \\
\text { involved in the community. }\end{array}$ & 94.7 & 84.2 \\
\hline C. Civil service organizations should attend various cultural festivals. & 84.2 & 73.7 \\
\hline C. Civil service organizations should provide information booth at job fairs and festivals. & 89.5 & 84.2 \\
\hline $\begin{array}{l}\text { C. Civil service personnel should conduct workshops in the community about their } \\
\text { organization. }\end{array}$ & 89.5 & 73.7 \\
\hline $\begin{array}{l}\text { T. Civil service organizations should design their websites to include video and written } \\
\text { testimonials from current employees to promote the connection of the work duties with } \\
\text { social goals. }\end{array}$ & 89.5 & 84.2 \\
\hline $\begin{array}{l}\text { T. Civil service organizations should advertise job announcements on radio stations } \\
\text { popular among African Americans. }\end{array}$ & 84.2 & 78.9 \\
\hline T. Civil service organizations should have web-based application processes. & 100.0 & 94.7 \\
\hline $\begin{array}{l}\text { T. Civil service organizations should advertise their organizations through social media } \\
\text { such as the organization's website, Facebook, Twitter, Live Chat rooms, and LinkedIn. }\end{array}$ & 84.2 & 78.9 \\
\hline
\end{tabular}


G. Various forms of compensation should be generic benchmarked in the civil service $\quad 89.5 \quad 84.2$ including salaries, benefits, paid leave time and all other benefits offered to employees.

Note. Letters before statements represent the corresponding element: resources (R), partnership $(\mathrm{P})$, leadership (L), business intelligence (B), community development (C), technology (T), and generic benchmarking $(\mathrm{G})$.

\section{Round 3}

The Round 3 survey included the 23 tactical statements from Round 2 representing consensus. Participants chose their top five solutions then ranked them in order of highest to lowest preference. Of the 23 solution statements ranked for preference, the participants ranked six tactical solutions as most important. The highest weighted average possible was a 5. The top six (not top five as some items tied in ranking) items among the panel became the items for the Round 4. Table 3 contains the study results of the top six solutions for the importance along with the desirability, and feasibility of these solutions from Round 2.

TABLE 3

TOP SIX SOLUTIONS IN BUILDING A CIVIL SERVICE PIPELINE OF AFRICAN AMERICAN COLLEGE GRADUATES

\begin{tabular}{lccc}
\hline Prescribed order of implementation if not all at once. & $\begin{array}{c}\text { Importance } \\
\text { Average } \\
\text { ranking of } \\
\text { importance, } \\
\text { highest } \\
\text { possible is 5 }\end{array}$ & $\begin{array}{c}\text { Desirability } \\
\text { highest } \\
\text { possible is } \\
100 \%\end{array}$ & $\begin{array}{c}\text { Feasibility } \\
\text { pighest } \\
\text { posible is } \\
100 \%\end{array}$ \\
\hline $\begin{array}{l}\text { 1. Civil service organizations should provide } \\
\text { compensation packages that are competitive and } \\
\text { transparent. RESOURCE ELEMENT }\end{array}$ & 4.00 & 94.7 & 73.7 \\
\hline $\begin{array}{l}\text { 2. Civil service organizations should recruit at } \\
\text { professional workshops and conferences of African } \\
\text { Americans. PARTNERSHIP ELEMENT }\end{array}$ & 4.00 & 89.5 & 78.9 \\
\hline $\begin{array}{l}\text { 3. Civil service organizations should provide employees } \\
\text { and their families quality and affordable insurance that } \\
\text { includes health, dental, vision, disability and life } \\
\text { coverages. RESOURCE ELEMENT }\end{array}$ & 3.71 & 100 & 89.5 \\
\hline $\begin{array}{l}\text { 4. Civil service organizations should provide career } \\
\text { training and development opportunities. RESOURCE }\end{array}$ & 3.50 & 100 & 84.2 \\
ELEMENT & & & \\
\hline $\begin{array}{l}\text { 5. Civil service organizations should provide internships } \\
\text { to African American college students. RESOURCE } \\
\text { ELEMENT }\end{array}$ & 3.50 & 89.5 & 73.7 \\
\hline $\begin{array}{l}\text { 6. Civil service organizations should recruit from STEM } \\
\text { program organizations. PARTNERSHIP ELEMENT }\end{array}$ & 3.50 & 84.2 & 78.9 \\
\hline
\end{tabular}

\section{Round 4}

The Round 4 survey consisted of the top six solutions derived from the Round 3. Participants rated their confidence in this final list of six solutions for the development of a grand strategy for building a sustainable civil service employment pipeline for African American college graduates. For the final list of solutions, $80 \%$ of the panelists indicated their confidence level was certain or reliable in the six tactical solutions 
building the civil service pipeline, targeted at annual graduating classes of African American college students.

\section{DISCUSSION}

This study regards a methodology to develop solutions to build the African American civil service pipeline. No published research studies involved application of Delphi to explore how to address the problem of increasing African Americans in the civil service. The results revealed consensus about futureoriented solutions for the development of a grand strategy for building a sustainable pipeline of African American college graduates as civil servants. The discussion pertains to the implications of those top six tactical solutions that comprise the grand strategy in building this civil service pipeline.

\section{Competitive and Transparent Compensation Packages}

Civil service organizations should provide compensation packages that are competitive and transparent. Young professionals expect an employer to provide this tactic. Millennials want access to information (Hwang \& Griffiths, 2017; Stevens \& Nies, 2018) and may feel organizational leaders are being dishonest about the salaries and pay gaps when such salaries are not transparent. Transparency is also a desire for African Americans because they have experienced many incidents involving unequal pay, thus is an important issue to this workgroup (Buttner \& Lowe, 2017; Ren, 2019). The transparency component of this tactic attributes to an organization's attractiveness for both millennials and African Americans.

Funding may be problematic for this tactic as one participant indicated that some civil service agencies might lack the funding to afford comparable wages. Government leaders, despite lack of funding, still need to be attentive of appropriately balancing the pay scales throughout their organizations for employees of same attributes, credentials, and responsibilities regardless of gender and race (Laird, 2017). An improved pay balance in the civil service organization may contribute to more of the organization's positions being attractive to not only African American college graduate candidates but also current employees. African Americans have regard for those jobs that provide opportunities to earn a high income (Hernandez, Avery, Volpone, \& Kaiser, 2019). Civil service organizations that offer this tactic may have an increase of jobs with enticing compensation packages, enabling more positions to be of interest to African American college graduates.

\section{Recruiting at African American Workshops and Conferences}

Civil service organizations should recruit at professional workshops and conferences of African Americans. Professional conferences and workshops of African Americans are ideal sources for the pipeline's candidates because individuals who attend these events are there for training, education, and to benefit their personal lives (West, 2017). Attendees of these events may learn general knowledge about being a professional or specific knowledge about a particular career (Ki \& Wang, 2016). These conferences and workshops are a venue for members to have the potential opportunity to learn and rehearse a particular job skill with someone already in that field. This type of opportunity can help validate the knowledge of the member who is seeking skills enhancement (Ki \& Wang, 2016). These events have formats to meet and cater to the members' needs (West, 2017), which is beneficial for a partnership with civil service organizations. A partnership between the leaders of civil service organizations and African American conferences and workshops can ensure that attendees of these conferences are educated with the pertinent information in being a successful civil service employee.

Group-specific events, such as African American conferences and workshops, enable their members to properly deal with the possible disadvantages minorities face in the workplace. Attendees at these events share their workplace experiences and share critical feedback to learn the respectful and proper ways of conducting themselves in pleasant and unpleasant workplace situations (West, 2017). At these groupspecific events, African Americans who are senior executives of their respective companies provide advice and serve as mentors to attendees ( $\mathrm{Ki} \&$ Wang, 2016). These mentoring relationships allow the members to have fruitful interactions through informal and formal dialogue where the mentors can appropriately 
groom the mentees in becoming a worthy employee in the workforce (West, 2017). The expert panel's high regard for recruiting from African American conferences and workshops is evidence they recognize the potential success of this tactic in building the civil service pipeline.

\section{Quality and Affordable Insurance}

This tactical solution pertains to the following resource element tactic: Civil service organizations should provide employees and their families quality and affordable insurance that includes health, dental, vision, disability, and life coverages. Kuehner-Hebert (2019) posited that college students rank insurance benefits as a high priority in choosing their first job. This tactic also provides coverage for the employees' family, which enables employees to have a sense of comfort knowing their family members will be covered in the event of the employees' injury or death (Held, 2018). Insurance packages that candidates and employees appreciate enable the organization to recruit future talent and retain employees (Barbour, 2018). African American college graduates may favor a civil service career because the government usually has an advantage over the private sector in providing better insurance packages (Kersting \& Kuhn, 2018).

For the civil service, the government budget influences many decisions of a civil service leader (Pynes $\&$ Rissler, 2017). The current study's expert panel acknowledged that this tactic was not only constrained by employer funds and rising healthcare costs but also political decisions. Civil service organizations should not allow funding issues to impair this recruitment tactic. Civil service leaders must continue to offer quality and affordable insurance, thus sustaining the civil service's edge over other sectors in this tactic.

\section{Career Training and Development Opportunities}

This solution pertains to the following tactic: Civil service organizations should provide career training and development opportunities. Training and development programs allow an organization to build the competencies of the employee and enhance the innovative perspectives that derive from the organization's diverse talent (Watson, Rogers, Watson, \& Liau-Hing Yep, 2019). This tactic enables employees to be prepared for broader work positions and management positions and to have a better sense of the organization's current and future needs and goals (Schroth, 2019). Career training and development can ensure that the civil service has a fruitful pool of African American candidates and an employee base of African American leadership successors (Chanland \& Murphy, 2018).

Burkett and Holliday (2018) posited that a key component for the government sector to attract young and diverse talent requires this sector to offer continuous training and development as an employment attribute. The African American workgroup is highly interested in this tactical solution. African American students not only appreciate those organizations that offer career training and development opportunities but also have a higher value in those organizations than Caucasian students (Stark \& Poppler, 2018). African Americans value training and development opportunities because this tactic prevents the perpetuation of inequalities in skills accustomed to African American employees (Ying Liao, Soltani, Wang, \& Iqbal, 2017).

Training and development opportunities include those vital instances such that organizational leaders offer African Americans to act in a supervisory position, which increases the African African's chance of being promoted in government (Frenkel \& Bednall, 2016). Training and development in the civil service must be objective and standardized such that all employees have equal opportunities for training; African Americans are not usually provided as many training and development opportunities as their Caucasian counterparts (King, 2017). With this tactic, civil service leaders can identify and use the contributions of those high-potential African American employees who might have been overlooked (Schaffer, 2019). When funding is scarce for this tactic, civil service leaders can also implement a lottery selection to determine which employees receive training (van Gerwen, Buskens, \& van der Lippe, 2018).

\section{Internships to African American College Students}

The next solution for building the pipeline involves this tactic: Civil service organizations should provide internships to African American college students. Internships provide real-life work experience that allows interns to align their academic backgrounds with practical applications (Montague \& Violette, 
2017). Organizations with internship programs allow organizational leaders to find those employees with original perspectives and a passion for that career field (Snellenberger-Holm, 2018). Long-term organizational cost savings may also be associated with an internship because hiring the intern may reduce some of the supplemental training that is normative for new hires (Snellenberger-Holm, 2018). Through an internship, the intern and employer can gauge each other as to how the employee-employer relationship may exist (Deschaine \& Jankens, 2017). Internships are also helpful to a student's college experience. Interns, in their return to college, may have an increased motivation to intensify their studies so that they can prepare themselves to be legitimate candidates in the workforce after graduation (Crowell, 2018).

Internships may allow students to validate their opinions of a career field. This validating experience is useful for civil service leaders because these leaders can use internships to change the negative preconceived thoughts students may have for government employment (Bates, 2016). While those students may only be an intern for the cash, civil service leaders need to embrace such an opportunity to show these students that government work is satisfying and rewarding (Bates, 2016). Government internships should include in-depth organizational projects that instill the interns with satisfaction and worthiness upon completion of the projects (Bates, 2016). The propaganda of the civil service internship must be that of a wonderful experience, not that of a miserable experience.

Civil service internships that include a diversity of interns must be a priority for government leaders. Diversity among interns was a concern of the current study's expert panel; they acknowledged that internship programs need to include students from minority campuses. African American college students who are included in civil service internship experiences may be able to bestow the benefits of such an experience. Those African American students who complete civil service internship programs may have an increased chance of government employment because internships are a potent tool for an organization's permanent hiring (Snellenberger-Holm, 2018). These African American interns may also start their civil service career in a position higher than entry-level due to having the internship experience (Mitnick, 2017).

\section{Recruiting From STEM Program Organizations}

The last solution for composing a grand strategy for building the civil service African American college graduate pipeline is this partnership tactic: Civil service organizations should recruit from STEM programs. STEM program organizations foster an environment that enables students to adjust and feel welcomed to the STEM community, as the STEM community is a culture of its own (Brown et al., 2016). For African American collegians, this STEM experience may enhance their capacity to adapt to the various cultures within the civil service.

College graduates recognize the existence of high-profile projects in government, and these students are interested in these challenging projects (Center for New American Security, 2019). STEM program organizations provide the training that enhances both the critical thinking and technical skills of the learners (Noonan, 2017) thus enables these learners to accomplish difficult tasks. These students' elevated thinking ability blends well with their intrigue for enigmas as STEM students enjoy solving puzzles and problems (Abel, 2017). The civil service can nurture the STEM students' affinity of understanding conundrums for solving the problems in government.

STEM program students have both a high regard for education, thus a high potential to be life-long learners (Noonan, 2017). Once these students become full-time civil service employees, they may contribute new knowledge to their workplace. Through the tactic of recruiting from STEM program

organizations, civil service leaders may be able to close the critical skills gap in the government sector's STEM-educated workforce (U.S. OPM, 2019).

\section{IMPLICATIONS TO PRACTICE}

The outcomes of the study may contribute to positive social change by increasing the number of African American mid- to senior-level managers employed in the civil service. This increase of African American college graduates in the civil service may be paramount for social change as increasing the number of people in a group can contribute to that group obtaining beneficial outcomes and favorable bureaucratic 
actions (Riccucci \& Van Ryzin, 2016). This study may generate reasoning for civil service leaders to create or modify organizational policies for suitable representation for all their organizations' members (Morabito \& Shelley, 2015). More African Americans may have the opportunity to have a career in the civil service, which may yield a more proportionate socially responsible citizenry and a healthier, more economically competitive economy (Alexander \& Arceneaux, 2015). Positive social change must be driven from the inside out to ensure a government for the people by the people.

The multitude of entities that have contributed to reconciling government's African American pipeline problem represent government agencies, African American organizations, community-based initiatives, and task forces such as U.S. OPM, EEOC, U.S. DOJ, Blacks in Government, African American Federal Executives Association, Community Alliance for Diversity, and Task Force on 21st Century Policing (EEOC, 2013; Nishishiba, 2012; U.S. DOJ \& EEOC, 2016; U.S. OPM, 2018). These entities should present the current study's grand strategy for building the pipeline to civil service leaders and endorse the authorization of the top six solutions with these leaders. Civil service leaders should evaluate immediately and employ these six solutions all at once, as the solutions were derived from the rich, diverse, and practical knowledge of experts who have been immersed in the phenomenon (Shorten \& Moorley, 2014).

The experts deemed the solutions desirable, feasible, and important, and $80 \%$ of the experts believed certain or reliable in the effectiveness of the solutions to build the pipeline. If implementing the solutions all at once is not possible, the following order of implementation is recommended.

1. Civil service organizations should provide compensation packages that are competitive and transparent.

2. Civil service organizations should recruit at professional workshops and conferences of African Americans.

3. Civil service organizations should provide employees and their families quality and affordable insurance that includes health, dental, vision, disability and life coverages.

4. Civil service organizations should provide career training and development opportunities.

5. Civil service organizations should provide internships to African American college students.

6. Civil service organizations should recruit from STEM program organizations.

This prescribed order of implementation is with consideration to the measure of importance of the solution as the first precedence and the desirability of the solution as the secondary precedence due to equal importance among some of the solutions. Solutions 1 and 2 were equally important, and Solutions 4, 5, and 6 were equally important.

Government leaders should use this study's top six pipeline solutions to proactively balance civil service workforce demographics and avoid possible diversity infractions as greater numbers of baby boomers continue to retire (Alba \& Barbosa, 2016). A sustainable pipeline of African American college graduates as candidates for recruitment into entry-level jobs in the civil service could uphold the civil service's mission of creating social equity and shared values for a diverse workforce (Durant \& Rosenbloom, 2016).

This study's recommendations for building the African American pipeline may attribute to civil service personnel's eagerness in implementing a diversity strategy at their organizations. These individuals have possibly experienced numerous unsuccessful attempts for workforce diversity and may be leery about trying more diversity solutions because humans remember the negative history of a venture and maintain those adverse feelings when the venture presents itself again (Stouten, Rousseau, \& De Cremer, 2018). This study's pipeline recommendations are grounded in collaboration, which has been a difficult approach for government organizations to accomplish due to differences in their respective cultures and practices (Willem \& Lucidarme, 2014). Civil service leaders should have confidence in the findings because this Delphi study potentially addressed the differences in concepts among civil service talent managers to develop practical agreement of the solutions that may be successfully scaled across the government spectrum (Bosun \& Modrak, 2014). 


\section{IMPLICATIONS TO RESEARCH}

The problem of recruiting college graduates into civil service positions is not confined to African Americans. Federal agencies are ineffective in the annual recruitment of millennial college graduates into the workforce, despite college students expressing an interest in government service (NACE, 2014). To face this challenge, federal human resource talent managers have considered a variety of strategies to build a pipeline that can be sustained annually and that comprises African American college graduates (NACE, 2014).

This ordeal of recruitment is a revived priority as recruitment had not been a focus in nearly 2 decades (Al Ariss et al., 2014; Cappelli \& Keller, 2014). Practitioners and scholars have both agreed that recruitment is a priority (Ryan \& Derous, 2016), but knowledge of recruitment solutions that can produce the desired results across the government sector have been still lacking. Recruitment involves the first stage of talent management (Schiemann, 2014), and solutions for this stage may enhance its effectiveness. The current study was used to identify recruitment solutions that may yield the desired results. This study contributes to an enhanced understanding of necessity and appreciation for recruitment and enables researchers to regard recruitment as an invaluable employment stage that must entail desirable, feasible, and important strategies. This Delphi study narrowed the gap in knowledge by providing scholars and practitioners with consensus-based elements and tactics of a grand strategy for creating a sustainable pipeline of candidates for recruitment into entry-level jobs in the civil service targeted at annual graduating classes of African American college students.

The findings of the current study reinforce the breakdown of a strategy into various elements (substrategies and tactics) as propositioned in the theory of strategy to effectively address a problem. The grand strategy represented the extent of the strategy breakdown, which entailed researching the body of literature to identify all the relevant elements and associated tactics as a conceptual framework for addressing the civil service African American pipeline. This study's findings substantiated the achievement of the conceptual framework for discovering all the relevant elements of the pipeline problem. This framework achievement implies that government agencies can thoroughly recognize the various elements of not only their respective pipeline problems but also any of their problems by employing a grand strategy. Another implication of the current study's findings is that the practitioner's knowledge is pertinent in supplementing the body of literature because the panel of this study also suggested tactics that met the established levels of consensus.

\section{STUDY LIMITATIONS}

This study had several limitations. One weakness, although the participants self- validated their ability to meet the expert criteria, no measures or a background check were in place to verify qualifications thus participants were considered truthful in their qualifications for the study. The study outcomes are transferable to organizations with similar social priorities to those of the government, such as nonprofit organizations and social purpose businesses, and may not be transferable to employment sectors that are dissimilar to the government, such as the private sector. Even though the participants could have experiences in the private sector, their opinions regarding the study problem might have been confined to government employment, reducing the applicability of the outcomes for the private sector. The limits of transferability are still reserved for the interpretation of the user of the findings and is dependent upon the perceived relevance and credibility of the panel backgrounds. Bias in this study's qualitative method could have been in the form of participants' satisfying personal agendas or having distorted ideas and subjective opinions. Due to the number of rounds, participants may have felt that the survey had become a burden yet continued but may have been less methodical as usual in their survey opinions. 


\section{CONCLUSION}

The lack of effective strategies to build the African American college graduate pipeline in the civil service is not allowing this sector to fulfill its merit of equal employment for all demographic groups or society's demand for a diverse workforce. Diversity in the talent pipelines lends to creative workforces of broad perspectives allowing their organizations to be resilient, thus evolving with society. The purpose of this study was to build consensus for the development of a Grand Strategy for building a sustainable pipeline of candidates in the civil service targeted at annual graduating classes of African American college students. A qualitative modified Delphi design was employed consisting of four rounds of surveys involving government-affiliated talent managers as panel participants. The panel developed a grand strategy where $80 \%$ of the panelists believed certain or reliable in the effectiveness of this grand strategy to build the pipeline. Members of society are demanding the civil service to address the low representation of African Americans in its workforce, and this study's Delphi design, grand strategy and findings must be considered by government leaders to provide society with the social response it deserves.

\section{ACKNOWLEDGMENT}

Special thank you to Kenneth C. Sherman for his contribution to this research.

\section{REFERENCES}

Abel, R. (2017). Priming the pipeline. SC Magazine, 28(4), 24-27. Retrieved from https://scmagazine.com Al Ariss, A., Cascio, W.F., \& Paauwe, J. (2014). Talent management: Current theories and future research directions. Journal of World Business, 49(2), 173-179. doi:10.1016/j.jwb.2013.11.001

Alba, R., \& Barbosa, Y.G. (2016). Room at the top? Minority mobility and the transition to demographic diversity in the USA. Ethnic and Racial Studies, 39(6), 917-938. doi:10.1080/01419870.2015.1081966

Alexander, F.K., \& Arceneaux, A. (2015). Envisioning a modern federal-state partnership in the reauthorization of the HEA as an engine to increase social mobility. Journal of Student Financial Aid, 45(3), 65-72. Retrieved from https://publications.nasfaa.org/jsfa/

Barbour, T. (2018). Attract employees, improve health. Alaska Business Monthly, 34(5), 24-28. Retrieved from https://www.akbizmag.com

Bartlett, C.A., \& Ghoshal, S. (1994). Changing the role of top management: Beyond strategy to purpose. Harvard Business Review, 72(6), 79-88. Retrieved from https://hbr.org

Bates, S. (2016). Government struggles to attract young workers: How local, state, and federal government recruiters can attract more millennial job seekers. HR Magazine, 61(10), 56-61. Retrieved from https://www.shrm.org/hr-today/news/hr-magazine/1216/Pages/federalgovernment-struggles-to-attract-young-workers.aspx

Benditt, L. (2015). Race, gender, and public-sector work: Prioritizing occupational values as a labor market privilege. Research in Social Stratification and Mobility, 42, 73-86. doi:10.1016/j.rssm.2015.09.001

Bosun, P., \& Modrak, V. (2014). Using the Delphi method in forecasting tourism activity. International Letters of Social and Humanistic Sciences, 25, 66-72. doi:10.18052/www.scipress.com/ILSHS.25.66

Boynton, P. (2015). Lesson plan. Can teach for America also teach the federal government about hiring millennials? Government Executive. Retrieved from https://www.govexec.com/magazine/features/2015/05/lesson-plan/111952/

Brady, S.R. (2015). Utilizing and adapting the Delphi method for use in qualitative research. International Journal of Qualitative Methods, 14(5), 1-6. doi:10.1177/1609406915621381

Brooks, D., Dougherty, B., \& Price, J. (2015). The federal government as a model employer and its impact on employment civil rights in America. Employee Rights \& Employment Policy Journal, 
19(2), 151-187. Retrieved from https://www.kentlaw.iit.edu

Brown, B.A., Henderson, J.B., Gray, S., Donovan, B., Sullivan, S., Patterson, A., \& Waggstaff, W. (2016). From description to explanation: An empirical exploration of the African-American pipeline problem in STEM. Journal of Research in Science Teaching, 53(1), 146-177. doi:10.1002/tea.21249

Burkett, H., \& Holliday, T. (2018). Can government organizations really be a magnet for talent? Talent Development, 72(6), 50-55. Retrieved from https://www.td.org

Buttner, E.H., \& Lowe, K.B. (2017). The relationship between perceived pay equity, productivity, and organizational commitment for US professionals of color. Equality, Diversity and Inclusion: An International Journal, 36(1), 73-89. doi:10.1108/edi-02-2016-0016

Cappelli, P., \& Keller, J.R. (2014). Talent management: Conceptual approaches and practical challenges. Annual Review of Organizational Psychology and Organizational Behavior, 1(1), 305-331. doi:10.1146/annurev-orgpsych-031413-091314

Cauchon, D. (2017). Creating a culture of diversity. Electric Perspectives, 42(3), 34-41. Retrieved from http://www.eei.org

Center for New American Security. (2019). Managing the national security workforce crisis. Retrieved from https://www.cnas.org/publications/commentary/managing-the-national-security-workforcecrisis

Chaffee, E.E. (1985). Three models of strategy. Academy of Management Review, 10(1), 89-98. doi: $10.2307 / 258215$

Chamberlain, G.P. (2010). Understanding strategy. Charleston, SC: CreateSpace.

Chanland, D.E., \& Murphy, W.M. (2018). Propelling diverse leaders to the top: A developmental network approach. Human Resource Management, 57(1), 111-126. doi:10.1002/hrm.21842

Crowell, T.L. (2018). Academic internships: To take or not to take? Students' assessments of public health fieldwork. Pedagogy in Health Promotion, 4(1), 19-34. doi:10.1177/2373379916684850

Cunningham, G.L., Avner, M.L., \& Justilien, R. (2014). The urgency of now: Foundations' role in ending racial inequity. The Foundation Review, 6(1), 51-65. doi:10.9707/1944-5660.1191

Deschaine, M.E., \& Jankens, B.P. (2017). Creating successful and sustainable educational administrative internship experiences. Higher Education, Skills and Work-Based Learning, 7(1), 5-20. doi:10.1108/HESWBL-02-2016-0008

Downs, K. (2016). African Americans over-represented among low-paying college majors. Retrieved from http://www.pbs.org/newshour/rundown/african-americans-over-represented-among-lowpaying-college-majors

Durant, R.F., \& Rosenbloom, D.H. (2016). The hollowing of American public administration. The American Review of Public Administration, pp. 1-25. doi:10.1177/0275074015627218

Equal Employment Opportunity Commission. (2013). African American workgroup report. Retrieved from https://www.eeoc.gov/federal/reports/aawg.cfm

Equal Employment Opportunity Commission. (2018). Job patterns for minorities and women in state and local government (EEO-4) [Tables]. Retrieved from https://www.eeoc.gov/eeoc/statistics/employment/jobpat-eeo4/2015/index.cfm

Festing, M., \& Schafer, L. (2014). Generational challenges to talent management: A framework for talent retention based on the psychological-contract perspective. Journal of World Business, 49(2), 262271. doi:10.1016/j.jwb.2013.11.010

Fletcher, A.J., \& Marchildon, G.P. (2014). Using the Delphi method for qualitative, participatory action research in health leadership. International Journal of Qualitative Methods, 13(1), 1-18. doi:10.1177/160940691401300101

Frenkel, S.J., \& Bednall, T. (2016). How training and promotion opportunities, career expectations, and two dimensions of organizational justice explain discretionary work effort. Human Performance, 29(1), 16-32. doi:10.1080/08959285.2015.1120306

Gallicano, T.D. (2013). Millennials' perceptions about diversity in their PR agencies. Public Relations Journal, 7(2), 37-70. Retrieved from http://apps.prsa.org 
Goddard, S.E., \& Krebs, R.R. (2015). Rhetoric, legitimation, and grand strategy. Security Studies, 24, 536. doi:10.1080/09636412.2014.1001198

Heitner, K.L., Kahn, A.E., \& Sherman, K.C. (2013). Building consensus on defining success of diversity work in organizations. Consulting Psychology Journal: Practice and Research, 65(1), 58-73. doi: $10.1037 / \mathrm{a} 0032593$

Held, J. (2018). Benefit trends: Employee benefits key to recruitment and retention. Benefits Magazine, 55(9), 8-10. Retrieved from https://www.ifebp.org/Pages/default.aspx

Hernandez, M., Avery, D.R., Volpone, S.D., \& Kaiser, C.R. (2019). Bargaining while Black: The role of race in salary negotiations. Journal of Applied Psychology, 104(4), 581-592. doi:10.1037/ap10000363

Hofhuis, J., van der Zee, K.I., \& Otten, S. (2016). Dealing with differences: The impact of perceived diversity outcomes on selection and assessment of minority candidates. The International Journal of Human Resource Management, 27(12), 1319-1339. doi:10.1080/09585192.2015.1072100

Hwang, J., \& Griffiths, M.A. (2017). Share more, drive less: Millennials value perception and behavioral intent in using collaborative consumption services. Journal of Consumer Marketing, 34(2), 132146. doi:10.1108/jcm-10-2015-1560

Kerr, S. (2015). Race at work 2015. London, UK: Business in the Community. Retrieved from http://race.bitc.org.uk/system/files/research/race_equality_campaign_yougov_report_nov_2015_v full_vfinal_e.pdf

Kersting, M., \& Kuhn, S. (2018). How public sector employers can manage retiree health liabilities. Benefits Quarterly, 34(1), 36-43. Retrieved from http://www.iscebs.org/Resources/BQ/Pages/BenefitsQuarterly.aspx

Ki, E.J., \& Wang, Y. (2016). Membership benefits matter: Exploring the factors influencing members' behavioral intentions in professional associations. Nonprofit Management and Leadership, 27(2), 199-217. doi:10.1002/nml.21230

King, D. (2017). Forceful federalism against American racial inequality. Government and Opposition, 52(2), 356-382. doi:10.1017/gov.2016.52

Kuehner-Hebert, K. (2019). Class of 2019: How to attract the newest job seekers. BenefitsPro. Retrieved from https://www.benefitspro.com

Laird, J. (2017). Public sector employment inequality in the United States and the great recession. Demography, 54(1), 391-411. doi:10.1007/s13524-016-0532-4

Layton, P. (2012). The idea of grand strategy. The RUSI Journal, 157(4), 56-61. doi:10.1080/03071847.2012.714193

Linstone, H.A., \& Turoff, M. (Eds.). (1975). The Delphi method: Techniques and applications. Reading, MA: Addison-Wesley.

Linstone, H.A., \& Turoff, M. (Eds.). (2002). The Delphi method: Techniques and applications. Retrieved from https://pdfs.semanticscholar.org/8634/72a67f5bdc67e4782306efd883fca23e3a3d.pdf

McMillan, S.S., King, M., \& Tully, M.P. (2016). How to use the nominal group and Delphi techniques. International Journal of Clinical Pharmacy, 38(3), 655-662. doi:10.1007/s11096-016-0257-x

Meskell, P., Murphy, K., Shaw, D.G., \& Casey, D. (2014). Insights into the use and complexities of the policy Delphi technique. Nurse Researcher, 21(3), 32-39. doi:10.7748/nr2014.01.21.3.32.e342

Miles, M.B., Huberman, A.M., \& Saldana, J. (2014). Qualitative data analysis: A methods sourcebook (3rd ed.). Thousand Oaks, CA: Sage Publications.

Mintzberg, H. (1987). The strategy concept I: Five Ps for strategy. California Management Review, 30(1), 11-24. doi:10.2307/41165263

Mitchell, G.E., O'Leary, R., \& Gerard, C. (2015). Collaboration and performance: Perspectives from public managers and NGO leaders. Public Performance \& Management Review, 38(4), 684-716. doi:10.1080/15309576.2015.1031015

Mitnick, S. (2017). Inside look at the Illinois Commerce Commission. Public Utilities Fortnightly, 155(7), 8-17. Retrieved from https://www.fortnightly.com

Montague, N., \& Violette, G. (2017). The millennial internship experience: Balancing technical training 
with soft skills. The CPA Journal, 87(12), 42-45. Retrieved from https://www.cpajournal.com/

Morabito, M., \& Shelley, T.O.C. (2015). Representative bureaucracy: Understanding the correlates of the lagging progress of diversity in policing. Race and Justice, 5(4), 330-355. doi: $10.1177 / 2153368715575376$

National Association of Colleges and Employers. (2014). College students are attracted to federal service, but agencies need to capitalize on their interest. Retrieved from https://ourpublicservice.org/

Nelson, A.M. (2015). Exploring the lack of African Americans in the Department of Defense Senior Executive Service Corps (Doctoral dissertation). Retrieved from ProQuest Dissertations and Theses Global database. (Order No. 3738091)

Nishishiba, M. (2012). Local government diversity initiatives in Oregon: An exploratory study. State and Local Government Review, 44(1), 55-66. doi:10.1177/0160323x12439475

Noonan, R. (2017, March 30). STEM jobs: 2017 update (ESA Issue Brief \# 02-17). Washington, DC: Economics and Statistics Administration, U.S. Department of Commerce. Retrieved from http://www.esa.gov/reports/stem-jobs-2017-update

Patton, M.Q. (2015). Qualitative research \& evaluation methods (4th ed.). Thousand Oaks, CA: Sage Publications.

Ployhart, R.E., Schmitt, N., \& Tippins, N.T. (2017). Solving the supreme problem: 100 years of selection and recruitment at the Journal of Applied Psychology. Journal of Applied Psychology, 102(3), 291-304. doi:10.1037/ap10000081

Pynes, J.E., \& Rissler, G.E. (2017). Social equity in the Trump Era: What can local public administrators do to improve social equity for their residents and community in the face of federal cuts? State and Local Government Review, 49(1), 48-59. doi: 10.1177/0160323X17720267

Ren, C. (2019). Fluctuating courses and constant challenges: The two trajectories of Black-White earnings inequality, 1968-2015. Social Science Research, 77, 30-44. doi:10.1016/j.ssresearch.2018.10.002

Riccucci, N.M., \& Van Ryzin, G.G. (2016). Representative bureaucracy: A lever to enhance social equity, coproduction, and democracy. Public Administration Review, 77(1), 21-30. doi:10.1111/puar.12649

Ross, F.K., Wells, J.T., \& Clarke, A.T. (2014). A pipeline for diversity. Journal of Accountancy, 218(2), 48-53. Retrieved from http://www.journalofaccountancy.com

Ryan, A.M., \& Derous, E. (2016). Highlighting tensions in recruitment and selection research and practice. International Journal of Selection and Assessment, 24(1), 54-62. doi:10.1111/ijsa.12129

Sabharwal, M., \& Geva-May, I. (2013). Advancing underrepresented populations in the public sector: Approaches and practices in the instructional pipeline. Journal of Public Affairs Education, 19(4), 657-679. Retrieved from http://www.naspaa.org/initiatives/jpae/jpae.asp

Schaffer, B.S. (2019). Examining reactions to workplace diversity: The role of dissimilarity-attraction in teams. Canadian Journal of Administrative Sciences, 36(1), 57-69. doi:10.1002/cjas.1476

Schiemann, W.A. (2014). From talent management to talent optimization. Journal of World Business, 49(2), 281-288. doi:10.1016/j.jwb.2013.11.012

Schroth, H. (2019). Are you ready for Gen Z in the workplace? California Management Review, 61(3), 518. doi:10.1177/0008125619841006

Shorten, A., \& Moorley, C. (2014). Selecting the sample. Evidence Based Nursing, 17(2), 32-33. doi:10.1136/eb-2014-101747

Skulmoski, G.J., Hartman, F.T., \& Krahn, J. (2007). The Delphi method for graduate research. Journal of Information Technology Education: Research (JITE: Research), 6, 1-21. Retrieved from https://www.informingscience.org/Journals/JITEResearch/Overview

Snellenberger-Holm, S. (2018). The bottom line on internships. Business People, 31(6), 20-21. Retrieved from http://www.businesspeople.com/

Stark, E., \& Poppler, P. (2018). Considering heterogeneity within assumed homogenous generational cohorts. Management Research Review, 41(1), 74-95. doi:10.1108/mrr-06-2017-0193 
Stevens, K.P., \& Nies, M.A. (2018). Transforming nursing education in a 140-character world: The efficacy of becoming social. Journal of Professional Nursing, 34(1), 31-34. doi:10.1016/j.profnurs.2017.07.001

Stewart, C. (2016). How diverse is your pipeline? Developing the talent pipeline for women and Black and ethnic minority employees. Industrial and Commercial Training, 48(2), 61-66. doi:10.1108/ICT-09-2015-0059

Stouten, J., Rousseau, D.M., \& De Cremer, D. (2018). Successful organizational change: Integrating the management practice and scholarly literatures. Academy of Management Annals, 12(2), 752-788. doi:10.5465/annals.2016.0095

U.S. Department of Justice \& Equal Employment Opportunity Commission. (2016). Advancing diversity in law enforcement. Retrieved from https://www.justice.gov/crt/policediversity

U.S. Office of Personnel Management. (2018). Federal Equal Opportunity Recruitment Program (FEOP) Report to Congress. Retrieved from https://www.opm.gov/policy-data-oversight/diversity-andinclusion/reports/\#url=Federal-Equal-Opportunity-and-Recruitment-Program

U.S. Office of Personnel Management. (2019). Stem workforce. Retrieved from https://www.opm.gov/blogs/Director/stem-workforce/

van Gerwen, N., Buskens, V., \& van der Lippe, T. (2018). Employee cooperative behavior in organizations: A vignette experiment on the relationship between training and helping intentions. International Journal of Training and Development, 22(3), 192-209. doi:10.1111/ijtd.12128

Watson, N.T., Rogers, K.S., Watson, K.L., \& Liau-Hing Yep, C. (2019). Integrating social justice-based conflict resolution into higher education settings: Faculty, staff, and student professional development through mediation training. Conflict Resolution Quarterly, 36(3), 251-262. doi: $10.1002 / \mathrm{crq} .21233$

Welsh, B. (2015). Mayor's plan to diversify LAFD ranks not working. Firehouse. Retrieved from https://www.firehouse.com/careers-education/article/12139422/firefighter-news-la-mayorgarcettis-overhaul-of-fire-department-hiring-not-working

West, N.M. (2017). A decade of a student affairs preconference program: Perceptions and characteristics of African American Women's Summit participants. College Student Affairs Journal, 35(1), 6985. doi:10.1353/csj.2017.0006

Willem, A., \& Lucidarme, S. (2014). Pitfalls and challenges for trust and effectiveness in collaborative networks. Public Management Review, 16(5), 733-760. doi:10.1080/14719037.2012.744426

Wilson, E. (2014). Diversity, culture and the glass ceiling. Journal of Cultural Diversity, 21(3), 83. Retrieved from http://www.tuckerpub.com/jcd

Ying Liao, Y., Soltani, E., Wang, W-Y., \& Iqbal, A. (2017). The dynamics of workplace relationships in a diverse internationally staffed organisation: A qualitative ethnographic assessment.

International Journal of Human Resource Management, 28(8), 1182-1211.

doi:10.1080/09585192.2016.1166788 